\title{
Sistem Pendukung Keputusan Pemilihan Menu Makanan bagi Anak dengan Metode Analitycal Hierarchy Process (AHP)
}

\author{
Yustria Handika Siregar ${ }^{1}$, Sri Rahayu ${ }^{2}$ \\ ${ }^{1,2,3}$ Program Studi Teknik Informatika, Universitas Asahan \\ Jln. Jend. Ahmad Yani Kisaran 21244, Sumatera Utara - Indonesia, telp/fax (0623)347222 \\ ${ }^{3}$ yustriahandikasiregaregmail.com ²ayurahayu.as5egmail.com
}

\begin{abstract}
Abstrak - Pemilihan menu makanan yang baik untuk anak merupakan faktor yang perlu diperhatikan untuk mengoptimalkan tumbuh kembang sang buah hati. Dalam hal ini, peran orang tua sangat dibutuhkan dalam pemilihan menu makanan yang baik untuk anak. Menu makanan yang dibutuhkan untuk anak harus mengandung zat gizi yang seimbang seperti karbohidrat, protein, kandungan serat, dan air. Seperti halnya pada anak-anak di TK Taqwa Perkebunan Gunung Melayu dimana pengaturan pola makan pada anak sangat bergantung pada pengetahuan ibu dalam memilih, mengolah serta mengatur makanan yang dibutuhkan untuk bekal sekolah sang anak. Untuk itu dibutuhkan suatu sistem pendukung keputusan dalam penentuan ranking menu makanan yang sehat dengan menggunakan metode AHP. Metode AHP membantu dalam pengambilan keputusan melalui perbandinganperbandingan yang komplek menjadi alternatif yang lebih akurat. Metode ini juga memungkinkan pengukuran skala rasio untuk bobot kriteria dan scoring alternatif. Sehingga diperoleh solusi atau hasil dari beberapa alternatif untuk diambil sebuah keputusan. Dengan adanya sistem pendukung keputusan pemilihan menu makanan bagi anak ini diharapkan dapat membantu orang tua dalam memilih menu makanan secara cepat dan sesuai untuk kebutuhan anak.
\end{abstract}

Kata kunci - Menu Makanan, Sistem Pendukung Keputusan, AHP

\section{PENDAHULUAN}

Menu makanan yang sehat sudah menjadi makanan wajib bagi anak yang berusia di bawah 6 tahun karena pada masa ini merupakan masa-masa emas sang anak untuk tumbuh dan berkembang dengan mengaktifkan segenap indera yang ia miliki. Untuk menunjang tumbuh kembangnya, sudah menjadi kewajiban bagi para orang tua menyiapkan menu makanan yang sehat dan bergizi yang dapat dikonsumsi oleh sang anak. Kerap kali para ibu dibuat ragu akan jenis makanan yang tepat dengan takaran yang sesuai setiap kali memberikan makanan untuk anak mereka.

Seperti halnya pada anak-anak di TK Taqwa Perkebunan Gunung Melayu dimana pengaturan pola makan pada anak sangat bergantung pada pengetahuan ibu dalam memilih, mengolah serta mengatur makanan yang dibutuhkan untuk bekal sekolah sang anak. Masalah makan yang terjadi pada anak umumnya adalah pola pemberian bekal yang salah dan masalah kesulitan makanan. Pemberian bekal sekolah pada anak hendaknya lebih memperhatikan kandungan gizi makanan agar kebutuhan gizi anak dapat terpenuhi dan mampu menunjang tumbuh kembang anak.

Oleh karena itu, dibutuhkan suatu sistem pendukung keputusan pemilihan menu makanan bagi anak, sehingga tercapai suatu keputusan yang baik dan optimal. Sistem pendukung keputusan ini juga berfungsi sebagai aplikasi yang dapat membantu orang tua dalam menentukan menu makanan sehat secara cepat dan akurat dengan cara memberikan alternatif pengambilan keputusan yang baik. Dalam penentuan rangking menu makanan yang sehat bagi anak, sistem pendukung keputusan ini menggunakan metode Analitycal Hierarchy Process (AHP) yang mampu memilih alternatif terbaik dari beberapa alternatif.

\section{LANDASAN TEORI}

A. Definisi Menu

Menu adalah suatu susunan beberapa macam hidangan yang disajikan pada waktu tertentu. Menu dapat terdiri dari satu macam hidangan yang lengkap atau tidak lengkap, juga dapat berupa hidangan untuk sarapan pagi, untuk makan siang atau makan malam saja ataupun hidangan makan untuk satu hari penuh dengan atau tanpa makanan selingan ${ }^{[1]}$. Menu adalah daftar pilihan makanan yang disiapkan untuk disajikan pada waktu tertentu.

\section{B. Definisi Makanan Sehat}

Makanan sehat adalah makanan yang kaya akan gizi yang seimbang, yang mengandung zat-zat yang dibutuhkan oleh tubuh dan tidak mengandung bahan yang berbahaya bagi tubuh. Makanan sehat dalam hal ini merupakan makanan bergizi seimbang sesuai dengan kebutuhan tubuh yang telah dijabarkan dalam pedoman umum gizi seimbang dan diantaranya adalah tidak mengandung zat-zat yang berbahaya bagi tubuh seperti zat-zat aditif atau zat-zat yang tidak termasuk bahan tambahan makanan yang diperbolehkan ${ }^{[2]}$.

\section{Defenisi Sistem}

Sistem adalah kumpulan beberapa unsur-unsur subsistem yang saling berkaitan antara satu dengan yang lainya sehingga membentuk kesatuan untuk mencapai suatu tujuan tertentu. Sebuah sistem terdiri 
dari berbagai unsur yang saling melengkapi dalam mencapai tujuan dan sasaran. Unsur-unsur yang terdapat dalam sistem itulah yang disebut dengan subsistem. Subsistem-subsistem tersebut harus saling berhubungan dan berinteraksi melalui komunikasi yang relevan sehingga sistem dapat bekerja secara efektif dan efisien ${ }^{[3]}$.

\section{Perancangan Sistem}

Perancangan sistem adalah merancang atau mendesain suatu sistem yang baik, yang di dalamnya berisi langkah-langkah operasi dalam proses pengolahan data dan prosedur untuk mendukung operasi suatu sistem. Perancangan sistem merupakan pengembangan sistem informasi baru berdasarkan hasil dari analisis kebutuhan ${ }^{[4]}$.

\section{E. Definisi Sistem Pendukung Keputusan}

Sistem pendukung keputusan merupakan suatu sistem informasi yang memberikan kemampuan pemecahan masalah yang digunakan untuk membantu proses pengambilan keputusan melalui alternatifalternatif dalam kondisi semi terstruktur dan tidak terstruktur.

Model yang menggambarkan proses pengambilan keputusan menurut Yustria ${ }^{[5]}$ terdiri dari empat fase yaitu:

1. Penelusuran (Intelligence)

Tahap ini merupakan tahap pendefinisian masalah serta identifikasi informasi yang dibutuhkan, berkaitan dengan persoalan yang dihadapi serta keputusan yang akan diambil.

\section{Perancangan (Design)}

Tahap ini merupakan proses untuk merepresentasikan model sistem yang akan dibangun berdasarkan pada asumsi yang telah ditetapkan.

\section{Pemilihan (Choice)}

Tahap ini merupakan suatu proses melakukan pengujian dan memilih keputusan terbaik berdasarkan kriteria tertentu yang telah ditentukan dan mengarah kepada tujuan yang akan dicapai.

\section{Implementasi (Implementation)}

Pada tahap ini perlu disusun serangkaian tindakan yang terencana, sehingga hasil keputusan dapat dipantau dan disesuaikan apabila diperlukan perbaikan-perbaikan.

\section{F. Definisi Analitycal Hierarchy Process (AHP)}

AHP (Analytical Hierarchy Process) adalah suatu teori umum tentang pengukuran yang digunakan untuk menemukan skala rasio, baik dari perbandingan berpasangan yang diskrit maupun kontinyu. AHP menguraikan masalah multi faktor atau multi kriteria yang kompleks menjadi suatu hirarki. Hirarki didefinisikan sebagai suatu representasi dari sebuah permasalahan yang kompleks dalam suatu struktur multi level dimana level pertama adalah tujuan, yang diikuti level faktor, kriteria, sub kriteria, dan seterusnya ke bawah hingga level terakhir dari alternatif. Dengan hirarki, suatu masalah yang kompleks dapat diuraikan ke dalam kelompokkelompoknya yang kemudian diatur menjadi suatu bentuk hirarki sehingga permasalahan akan tampak lebih terstruktur dan sistematis ${ }^{[6]}$.

\section{G. Tahapan-tahapan dalam AHP}

Tahapan-tahapan dalam AHP (Analytical Hierarchy Process) adalah sebagai berikut :

1. Membuat struktur hierarki yang diawali dengan tujuan umum, dilanjutkan dengan kriteria-kriteria dan alternatif- alternatif pilihan.

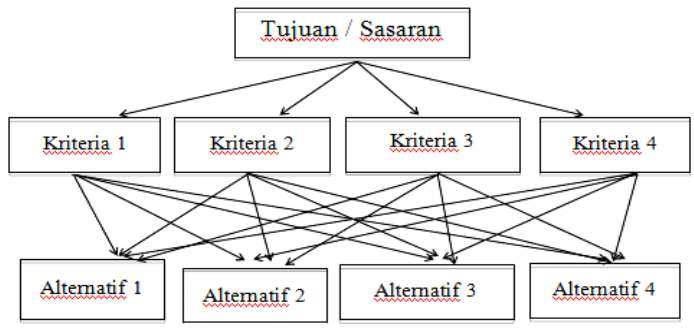

Gambar 1. Struktur Hierarki AHP

2. Membuat matrik perbandingan berpasangan yang menggambarkan kontribusi relatif elemen terhadap kriteria yang setingkat di atasnya.

TABEL 1

SKALA PERBANDINGAN BERPASANGAN

\begin{tabular}{|c|l|}
\hline $\begin{array}{c}\text { Tingkat } \\
\text { Kepentingan }\end{array}$ & \multicolumn{1}{c|}{ Defenisi } \\
\hline 1 & Kedua elemen sangat penting. \\
\hline 3 & $\begin{array}{l}\text { Elemen A sedikit lebih penting dari } \\
\text { elemen B. }\end{array}$ \\
\hline 5 & $\begin{array}{l}\text { Elemen A sangat penting dibanding } \\
\text { elemen B. }\end{array}$ \\
\hline 7 & $\begin{array}{l}\text { Elemen A sangat jelas lebih penting } \\
\text { dibanding B. }\end{array}$ \\
\hline $2,4,6,8$ & $\begin{array}{l}\text { Elemen A mutlak lebih penting dari } \\
\text { elemen B. }\end{array}$ \\
\hline & $\begin{array}{l}\text { Nilai tengah diantara dua penilaian } \\
\text { berurutan. }\end{array}$ \\
\hline
\end{tabular}

3. Menormalkan data yaitu dengan membagi nilai dari setiap elemen di dalam matriks yang berpasangan dengan nilai total dari setiap kolom.

4. Menghitung eigen vector dari setiap matriks perbandingan berpasangan.

5. Mengulangi langkah 3, 4 dan 5 untuk seluruh tingkat hirarki.

6. Menguji konsistensi hirarki. Jika tidak memenuhi dengan $\mathrm{CR}<0,100$ maka penilaian harus diulangi kembali.

TABEL 2

DAFTAR INDEKS RANDOM KONSISTENSI

\begin{tabular}{|c|c|c|c|c|c|c|c|c|c|c|}
\hline Ukuran & 1 & 2 & 3 & 4 & 5 & 6 & 7 & 8 & 9 & 10 \\
\hline Nilai IR & $\mathbf{0}$ & $\mathbf{0}$ & $\mathbf{0 , 5 8}$ & $\mathbf{0 , 9}$ & $\mathbf{1 , 1 2}$ & $\mathbf{1 , 2 4}$ & $\mathbf{1 , 3 2}$ & $\mathbf{1 , 4 1}$ & $\mathbf{1 , 4 5}$ & $\mathbf{1 , 4 9}$ \\
\hline
\end{tabular}




\section{METODOLOGI PENELITIAN}

\section{A. Teknik Pengumpulan Data}

Untuk dapat menghimpun data-data tersebut maka teknik pengumpulan data dilakukan dengan beberapa teknik, yaitu :

1. Wawancara

Melalui wawancara ini diharapkan dapat dihimpun informasi dari TK Taqwa Perkebunan Gunung Melayu tentang pemilihan menu makanan bagi anak.

2. Kuisioner

Kuisioner ini dilakukan untuk melihat tanggapan atau umpan balik dari Taman Kanak-kanak beserta dari orang tua anak.

3. Studi lapangan

Melakukan pengamatan langsung dengan memperhatikan aspek makanan sehat serta faktorfaktor yang dapat menjadi pertimbangan dalam sistem ini. Misalnya tingkat kesadaran orang tua tentang makanan sehat untuk anak.

\section{ANALISA DAN PEMBAHASAN}

A. Analisis Proses Metode AHP

1. Menentukan nilai perbandingan matriks berpasangan antara satu kriteria dengan kriteria yang lain.

TABEL 3

MATRIKS PERBANDINGAN BERPASANGAN

\begin{tabular}{|c|c|c|c|c|}
\hline Kriteria & 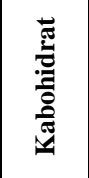 & 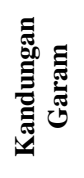 & 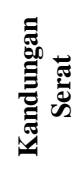 & 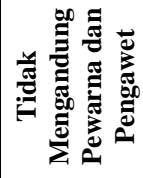 \\
\hline Kabohidrat & 1,00 & 0,20 & 2,00 & 0,14 \\
\hline Kandungan Garam & 5,00 & 1,00 & 6,00 & 0,33 \\
\hline Kandungan Serat & 0,50 & 0,17 & 1,00 & 0,20 \\
\hline $\begin{array}{c}\text { Tidak Mengandung } \\
\text { Pewarna dan Pengawet }\end{array}$ & 7,00 & 3,00 & 5,00 & 1,00 \\
\hline Jumlah & $13, .50$ & 4,37 & 14,00 & 1,68 \\
\hline
\end{tabular}

2. Membuat matriks nilai kriteria dengan rumus :

Nilai baris kolom baru = nilai baris kolom lama / jumlah masing-masing kolom lama

TABEL 4

MATRIKS NILAI KRITERIA

\begin{tabular}{|c|c|c|c|c|c|}
\hline Kriteria & 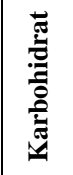 & 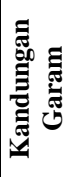 & 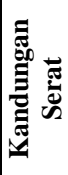 & 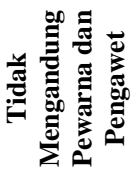 & 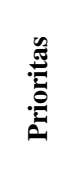 \\
\hline Karbohidrat & 0,074 & 0,046 & 0,143 & 0,085 & 0,087 \\
\hline Kandungan Garam & 0,370 & 0,229 & 0,429 & 0,199 & $\mathbf{0 , 3 0 7}$ \\
\hline Kandungan Serat & 0,037 & 0,038 & 0,071 & 0,119 & 0,066 \\
\hline $\begin{array}{c}\text { Tidak Mengandung } \\
\text { Pewarna dan Pengawet }\end{array}$ & 0,519 & 0,687 & 0,357 & 0,597 & 0,540 \\
\hline Jumlah & 1,000 & 1,000 & 1,000 & 1,000 & $\mathbf{1 , 0 0 0}$ \\
\hline
\end{tabular}

3. Membuat matriks penjumlahan tiap baris dengan mengalikan nilai prioritas dengan matriks berpasangan.

TABEL 5

MATRIKS PENJUMLAHAN TIAP BARIS

\begin{tabular}{|c|c|c|c|c|c|}
\hline Kriteria & 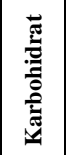 & 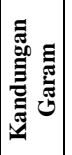 & 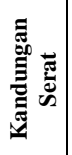 & 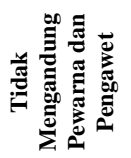 & 宽 \\
\hline Karbohidrat & 0,087 & 0,061 & 0,133 & 0,077 & 0,358 \\
\hline Kandungan Garam & 0,435 & 0,307 & 0,399 & 0,180 & 1,321 \\
\hline Kandungan Serat & 0,043 & 0,051 & 0,066 & 0,108 & 0,269 \\
\hline $\begin{array}{l}\text { Tidak Mengandung } \\
\text { Pewarna dan Pengawet }\end{array}$ & 0,609 & 0,920 & 0,332 & 0,540 & 2,401 \\
\hline
\end{tabular}

4. Perhitungan rasio konsistensi.

TABEL 6

PERHITUNGAN RASIO KONSISTENSI

\begin{tabular}{|c|c|c|c|}
\hline Kriteria & $\begin{array}{c}\text { Jumlah Tiap } \\
\text { Baris }\end{array}$ & Prioritas & Hasil \\
\hline Karbohidrat & 0,358 & 0,087 & 4,120 \\
\hline Kandungan Garam & 1,321 & 0,307 & 4,306 \\
\hline Kandungan Serat & 0,269 & 0,066 & 4,047 \\
\hline $\begin{array}{c}\text { Tidak Mengandung } \\
\text { Pewarna dan Pengawet }\end{array}$ & 2,401 & 0,540 & 4,448 \\
\hline \multicolumn{3}{|c|}{ Jumlah } & $\mathbf{1 6 , 9 2 1}$ \\
\hline
\end{tabular}

Jumlah (jumlah dari nilai-nilai hasil) $=16,921$

$\mathrm{n}$ (jumlah kriteria) $=4$

$\lambda$ maks $(16,921 / 4)=4,230$

$\mathrm{CI}=(4,230-4) /(4-1)=0,077$

$\mathrm{CR}=0,077 / 0,90=0,0853$

B. Menentukan Nilai Matriks Makanan Anak Per Kriteria

1. Kriteria Karbohidrat

TABEL 7

MATRIKS PERBANDINGAN BERPASANGAN KRITERIA KARBOHIDRAT

\begin{tabular}{|c|c|c|c|c|}
\hline Altermatif & $\begin{array}{c}\text { Udang } \\
\text { Goreng } \\
\text { Tepung }\end{array}$ & $\begin{array}{c}\text { Tumis } \\
\text { Tahu Saus } \\
\text { Tiram }\end{array}$ & $\begin{array}{c}\text { Tumis } \\
\text { Brokoli }\end{array}$ & $\begin{array}{c}\text { Sup } \\
\text { Ayam }\end{array}$ \\
\hline $\begin{array}{c}\text { Udang Goreng } \\
\text { Tepung }\end{array}$ & 1,00 & 0,50 & 5,00 & 0,33 \\
\hline $\begin{array}{c}\text { Tumis Tahu } \\
\text { Saus Tiram }\end{array}$ & 2,00 & 1,00 & 7,00 & 0,50 \\
\hline Tumis Brokoli & 0,20 & 0,14 & 1,00 & 0,11 \\
\hline Sup Ayam & 3,00 & 2,00 & 9,00 & 1,00 \\
\hline Jumlah & $\mathbf{6 , 2 0}$ & $\mathbf{3 , 6 4}$ & $\mathbf{2 2 , 0 0}$ & $\mathbf{1 , 9 4}$ \\
\hline
\end{tabular}

TABEL 8

MATRIKS NILAI KRITERIA KARBOHIDDRAT

\begin{tabular}{|c|c|c|c|c|c|}
\hline Alternatif & $\begin{array}{c}\text { Udang } \\
\text { Goreng } \\
\text { Tepung }\end{array}$ & $\begin{array}{c}\text { Tumis } \\
\text { Tahu } \\
\text { Saus } \\
\text { Tiram }\end{array}$ & $\begin{array}{c}\text { Tumis } \\
\text { Brokoli }\end{array}$ & $\begin{array}{c}\text { Sup } \\
\text { Ayam }\end{array}$ & Prioritas \\
\hline $\begin{array}{c}\text { Udang } \\
\text { Goreng } \\
\text { Tepung }\end{array}$ & 0,161 & 0,137 & 0,227 & 0,171 & $\mathbf{0 , 1 7 4}$ \\
\hline $\begin{array}{c}\text { Tumis Tahu } \\
\text { Saus Tiram }\end{array}$ & 0,323 & 0,275 & 0,318 & 0,257 & $\mathbf{0 , 2 9 3}$ \\
\hline $\begin{array}{c}\text { Tumis } \\
\text { Brokoli }\end{array}$ & 0,032 & 0,039 & 0,045 & 0,057 & $\mathbf{0 , 0 4 4}$ \\
\hline Sup Ayam & 0,484 & 0,549 & 0,409 & 0,514 & $\mathbf{0 , 4 8 9}$ \\
\hline Jumlah & $\mathbf{1 , 0 0 0}$ & $\mathbf{1 , 0 0 0}$ & $\mathbf{1 , 0 0 0}$ & $\mathbf{1 , 0 0 0}$ & $\mathbf{1 , 0 0 0}$ \\
\hline
\end{tabular}


TABEL 9

MATRIKS PENJUMLAHAN TIAP BARIS

\begin{tabular}{|c|c|c|c|c|c|}
\hline Alternatif & $\begin{array}{c}\text { Udang } \\
\text { Goreng } \\
\text { Tepung }\end{array}$ & $\begin{array}{c}\text { Tumis } \\
\text { Tahu } \\
\text { Saus } \\
\text { Tiram }\end{array}$ & $\begin{array}{c}\text { Tumis } \\
\text { Brokoli }\end{array}$ & $\begin{array}{c}\text { Sup } \\
\text { Ayam }\end{array}$ & Jumlah \\
\hline $\begin{array}{c}\text { Udang } \\
\text { Goreng } \\
\text { Tepung }\end{array}$ & 0,174 & 0,147 & 0,218 & 0,163 & $\mathbf{0 , 7 0 1}$ \\
\hline $\begin{array}{c}\text { Tumis Tahu } \\
\text { Saus Tiram }\end{array}$ & 0,348 & 0,293 & 0,305 & 0,245 & $\mathbf{1 , 1 9 1}$ \\
\hline $\begin{array}{c}\text { Tumis } \\
\text { Brokoli }\end{array}$ & 0,035 & 0,042 & 0,044 & 0,054 & $\mathbf{0 , 1 7 5}$ \\
\hline Sup Ayam & 0,522 & 0,586 & 0,392 & 0,489 & $\mathbf{1 , 9 9 0}$ \\
\hline
\end{tabular}

TABEL 10

MATRIKS RASIO KONSISTENSI

\begin{tabular}{|c|c|c|c|}
\hline Alternatif & $\begin{array}{c}\text { Jumlah Tiap } \\
\text { Baris }\end{array}$ & Prioritas & Hasil \\
\hline Udang Goreng Tepung & 0,701 & 0,174 & 4,024 \\
\hline Tumis Tahu Saus Tiram & 1,191 & 0,293 & 4,063 \\
\hline Tumis Brokoli & 0,175 & 0,044 & 4,012 \\
\hline Sup Ayam & 1,990 & 0,489 & 4,069 \\
\hline \multicolumn{2}{|c|}{ Jumlah } & 16,168 \\
\hline
\end{tabular}

Jumlah (jumlah dari nilai-nilai hasil) $=16,168$

$\mathrm{n}$ (jumlah kriteria) $=4$

$\lambda$ maks $(16,168 / 4)=4,0420$

$\mathrm{CI}=(4,0420-4) /(4-1)=0,0140$

$\mathrm{CR}=0,0140 / 0,90=0,0156$

2. Kriteria Jumlah Kandungan Garam

TABEL 11

MATRIKS PERBANDINGAN BERPASANGAN KRITERIA KANDUNGAN GARAM

\begin{tabular}{|c|c|c|c|c|}
\hline Altermatif & $\begin{array}{c}\text { Udang Goreng } \\
\text { Tepung }\end{array}$ & $\begin{array}{c}\text { Tumis Tahu } \\
\text { Saus Tiram }\end{array}$ & $\begin{array}{c}\text { Tumis } \\
\text { Brokoli }\end{array}$ & $\begin{array}{c}\text { Sup } \\
\text { Ayam }\end{array}$ \\
\hline $\begin{array}{c}\text { Udang Goreng } \\
\text { Tepung }\end{array}$ & 1,00 & 9,00 & 5,00 & 2,00 \\
\hline $\begin{array}{c}\text { Tumis Tahu } \\
\text { Saus Tiram }\end{array}$ & 0,11 & 1,00 & 0,11 & 0,11 \\
\hline Tumis Brokoli & 0,20 & 9,00 & 1,00 & 0,50 \\
\hline Sup Ayam & 0,50 & 9,00 & 2,00 & 1,00 \\
\hline Jumlah & $\mathbf{1 , 8 1}$ & $\mathbf{2 8 , 0 0}$ & $\mathbf{8 , 1 1}$ & $\mathbf{3 , 6 1}$ \\
\hline
\end{tabular}

TABEL 12

MATRIKS NILAI KRITERIA KANDUNGAN GARAM

\begin{tabular}{|c|c|c|c|c|c|}
\hline Alternatif & $\begin{array}{c}\text { Udang } \\
\text { Goreng } \\
\text { Tepung }\end{array}$ & $\begin{array}{c}\text { Tumis } \\
\text { Tahu Saus } \\
\text { Tiram }\end{array}$ & $\begin{array}{c}\text { Tumis } \\
\text { Brokoli }\end{array}$ & $\begin{array}{c}\text { Sup } \\
\text { Ayam }\end{array}$ & Prioritas \\
\hline $\begin{array}{c}\text { Udang } \\
\text { Goreng } \\
\text { Tepung }\end{array}$ & 0,552 & 0,321 & 0,616 & 0,554 & $\mathbf{0 , 5 1 1}$ \\
\hline $\begin{array}{c}\text { Tumis Tahu } \\
\text { Saus Tiram }\end{array}$ & 0,061 & 0,036 & 0,014 & 0,031 & $\mathbf{0 , 0 3 5}$ \\
\hline $\begin{array}{c}\text { Tumis } \\
\text { Brokoli }\end{array}$ & 0,110 & 0,321 & 0,123 & 0,138 & $\mathbf{0 , 1 7 3}$ \\
\hline Sup Ayam & 0,276 & 0,321 & 0,247 & 0,277 & $\mathbf{0 , 2 8 0}$ \\
\hline Jumlah & $\mathbf{1 , 0 0 0}$ & $\mathbf{1 , 0 0 0}$ & $\mathbf{1 , 0 0 0}$ & $\mathbf{1 , 0 0 0}$ & $\mathbf{1 , 0 0 0}$ \\
\hline
\end{tabular}

TABEL 13

MATRIKS PENJUMLAHAN TIAP BARIS

\begin{tabular}{|c|c|c|c|c|c|}
\hline Alternatif & $\begin{array}{c}\text { Udang } \\
\text { Goreng } \\
\text { Tepung }\end{array}$ & $\begin{array}{c}\text { Tumis Tahu } \\
\text { Saus Tiram }\end{array}$ & $\begin{array}{c}\text { Tumis } \\
\text { Brokoli }\end{array}$ & $\begin{array}{c}\text { Sup } \\
\text { Ayam }\end{array}$ & Jumlah \\
\hline $\begin{array}{c}\text { Udang Goreng } \\
\text { Tepung }\end{array}$ & 0,511 & 0,318 & 0,867 & 0,561 & $\mathbf{2 , 2 5 7}$ \\
\hline $\begin{array}{c}\text { Tumis Tahu } \\
\text { Saus Tiram }\end{array}$ & 0,057 & 0,035 & 0,019 & 0,031 & $\mathbf{0 , 1 4 3}$ \\
\hline Tumis Brokoli & 0,102 & 0,318 & 0,173 & 0,140 & $\mathbf{0 , 7 3 4}$ \\
\hline Sup Ayam & 0,255 & 0,318 & 0,347 & 0,280 & $\mathbf{1 , 2 0 1}$ \\
\hline
\end{tabular}

TABEL 14

MATRIKS RASIO KONSISTENSI

\begin{tabular}{|c|c|c|c|}
\hline Alternatif & Jumlah Tiap Baris & Prioritas & Hasil \\
\hline $\begin{array}{c}\text { Udang Goreng } \\
\text { Tepung }\end{array}$ & 2,257 & 0,511 & 4,417 \\
\hline $\begin{array}{c}\text { Tumis Tahu Saus } \\
\text { Tiram } \\
\end{array}$ & 0,143 & 0,035 & 4,029 \\
\hline Tumis Brokoli & 0,734 & 0,173 & 4,234 \\
\hline Sup Ayam & 1,201 & 0,280 & 4,285 \\
\hline \multicolumn{3}{|c|}{ Jumlah } & 16,965 \\
\hline
\end{tabular}

Jumlah (jumlah dari nilai-nilai hasil) $=16,965$

$\mathrm{n}$ (jumlah kriteria) $=4$

$\lambda$ maks $(16,965 / 4)=4,2414$

$\mathrm{CI}=(4,2414-4) /(4-1)=0,0805$

$\mathrm{CR}=0,0805 / 0,90=0,0894$

3. Kriteria Kandungan Serat

TABEL 14

MATRIKS PERBANDINGAN BERPASANGAN KRITERIA KANDUNGAN SERAT

\begin{tabular}{|c|c|c|c|c|}
\hline Altermatif & $\begin{array}{c}\text { Udang } \\
\text { Goreng } \\
\text { Tepung }\end{array}$ & $\begin{array}{c}\text { Tumis Tahu } \\
\text { Saus Tiram }\end{array}$ & $\begin{array}{c}\text { Tumis } \\
\text { Brokoli }\end{array}$ & $\begin{array}{c}\text { Sup } \\
\text { Ayam }\end{array}$ \\
\hline $\begin{array}{c}\text { Udang Goreng } \\
\text { Tepung }\end{array}$ & 1,00 & 6,00 & 0,50 & 0,50 \\
\hline $\begin{array}{c}\text { Tumis Tahu Saus } \\
\text { Tiram }\end{array}$ & 0,17 & 1,00 & 0,17 & 0,13 \\
\hline Tumis Brokoli & 2,00 & 6,00 & 1,00 & 2,00 \\
\hline Sup Ayam & 2,00 & 8,00 & 0,50 & 1,00 \\
\hline Jumlah & $\mathbf{5 , 1 7}$ & $\mathbf{2 1 , 0 0}$ & $\mathbf{2 , 1 7}$ & $\mathbf{3 , 6 3}$ \\
\hline
\end{tabular}

TABEL 16

MATRIKS NILAI KRITERIA KANDUNGAN SERAT

\begin{tabular}{|c|c|c|c|c|c|}
\hline Alternatif & $\begin{array}{c}\text { Udang } \\
\text { Goreng } \\
\text { Tepung }\end{array}$ & $\begin{array}{c}\text { Tumis } \\
\text { Tahu } \\
\text { Saus } \\
\text { Tiram }\end{array}$ & $\begin{array}{c}\text { Tumis } \\
\text { Brokoli }\end{array}$ & $\begin{array}{c}\text { Sup } \\
\text { Ayam }\end{array}$ & Prioritas \\
\hline $\begin{array}{c}\text { Udang } \\
\text { Goreng } \\
\text { Tepung }\end{array}$ & 0,194 & 0,286 & 0,231 & 0,138 & $\mathbf{0 , 2 1 2}$ \\
\hline $\begin{array}{c}\text { Tumis Tahu } \\
\text { Saus Tiram }\end{array}$ & 0,032 & 0,048 & 0,077 & 0,034 & $\mathbf{0 , 0 4 8}$ \\
\hline $\begin{array}{c}\text { Tumis } \\
\text { Brokoli }\end{array}$ & 0,387 & 0,286 & 0,462 & 0,552 & $\mathbf{0 , 4 2 2}$ \\
\hline Sup Ayam & 0,387 & 0,381 & 0,231 & 0,276 & $\mathbf{0 , 3 1 9}$ \\
\hline Jumlah & $\mathbf{1 , 0 0 0}$ & $\mathbf{1 , 0 0 0}$ & $\mathbf{1 , 0 0 0}$ & $\mathbf{1 , 0 0 0}$ & $\mathbf{1 , 0 0 0}$ \\
\hline
\end{tabular}


TABEL 17

MATRIKS PENJUMLAHAN TIAP BARIS

\begin{tabular}{|c|c|c|c|c|c|}
\hline Alternatif & $\begin{array}{c}\text { Udang } \\
\text { Goreng } \\
\text { Tepung }\end{array}$ & $\begin{array}{c}\text { Tumis Tahu } \\
\text { Saus Tiram }\end{array}$ & $\begin{array}{c}\text { Tumis } \\
\text { Brokoli }\end{array}$ & $\begin{array}{c}\text { Sup } \\
\text { Ayam }\end{array}$ & Jumlah \\
\hline $\begin{array}{c}\text { Udang Goreng } \\
\text { Tepung }\end{array}$ & 0,212 & 0,287 & 0,211 & 0,159 & $\mathbf{0 , 8 6 9}$ \\
\hline $\begin{array}{c}\text { Tumis Tahu } \\
\text { Saus Tiram }\end{array}$ & 0,035 & 0,048 & 0,070 & 0,040 & $\mathbf{0 , 1 9 3}$ \\
\hline Tumis Brokoli & 0,424 & 0,287 & 0,422 & 0,637 & $\mathbf{1 , 7 7 0}$ \\
\hline Sup Ayam & 0,424 & 0,383 & 0,211 & 0,319 & $\mathbf{1 , 3 3 6}$ \\
\hline
\end{tabular}

TABEL 18

MATRIKS RASIO KONSISTENSI

\begin{tabular}{|c|c|c|c|}
\hline Alternatif & $\begin{array}{c}\text { Jumlah Tiap } \\
\text { Baris }\end{array}$ & Prioritas & Hasil \\
\hline Udang Goreng Tepung & 0,869 & 0,212 & 4,099 \\
\hline Tumis Tahu Saus Tiram & 0,193 & 0,048 & 4,041 \\
\hline Tumis Brokoli & 1,770 & 0,422 & 4,199 \\
\hline Sup Ayam & 1,336 & 0,319 & 4,192 \\
\hline \multicolumn{2}{|c|}{ Jumlah } & 16,531 \\
\hline
\end{tabular}

Jumlah (jumlah dari nilai-nilai hasil) $=16,531$

$\mathrm{n}$ (jumlah kriteria) $=4$

$\lambda$ maks $(16,531 / 4)=4,1328$

$\mathrm{CI}=(4,1328-4) /(4-1)=0,0443$

$\mathrm{CR}=0,0443 / 0,90=0,0492$

4. Kriteria Tidak Mengandung Pewarna dan Pengawet

TABEL 19

MATRIKS PERBANDINGAN BERPASANGAN KRITERIA TIDAK MENGANDUNG PEWARNA DAN PENGAWET

\begin{tabular}{|c|c|c|c|c|}
\hline Altermatif & $\begin{array}{c}\text { Udang } \\
\text { Goreng } \\
\text { Tepung }\end{array}$ & $\begin{array}{c}\text { Tumis Tahu } \\
\text { Saus Tiram }\end{array}$ & $\begin{array}{c}\text { Tumis } \\
\text { Brokoli }\end{array}$ & $\begin{array}{c}\text { Sup } \\
\text { Ayam }\end{array}$ \\
\hline $\begin{array}{c}\text { Udang Goreng } \\
\text { Tepung }\end{array}$ & 1,00 & 0,11 & 0,25 & 0,17 \\
\hline $\begin{array}{c}\text { Tumis Tahu } \\
\text { Saus Tiram }\end{array}$ & 9,00 & 1,00 & 5,00 & 1,00 \\
\hline Tumis Brokoli & 4,00 & 0,20 & 1,00 & 0,33 \\
\hline Sup Ayam & 6,00 & 1,00 & 3,00 & 1,00 \\
\hline Jumlah & $\mathbf{2 0 , 0 0}$ & $\mathbf{2 , 3 1}$ & $\mathbf{9 , 2 5}$ & $\mathbf{2 , 5 0}$ \\
\hline
\end{tabular}

TABEL 19

MATRIKS NILAI KRITERIA TIDAK MENGANDUNG PEWARNA DAN PENGAWET

\begin{tabular}{|c|c|c|c|c|c|}
\hline Alternatif & $\begin{array}{c}\text { Udang } \\
\text { Goreng } \\
\text { Tepung }\end{array}$ & $\begin{array}{c}\text { Tumis Tahu } \\
\text { Saus Tiram }\end{array}$ & $\begin{array}{c}\text { Tumis } \\
\text { Brokoli }\end{array}$ & $\begin{array}{c}\text { Sup } \\
\text { Ayam }\end{array}$ & Prioritas \\
\hline $\begin{array}{c}\text { Udang Goreng } \\
\text { Tepung }\end{array}$ & 0,050 & 0,048 & 0,027 & 0,067 & $\mathbf{0 , 0 4 8}$ \\
\hline $\begin{array}{c}\text { Tumis Tahu } \\
\text { Saus Tiram }\end{array}$ & 0,450 & 0,433 & 0,541 & 0,400 & $\mathbf{0 , 4 5 6}$ \\
\hline Tumis Brokoli & 0,200 & 0,087 & 0,108 & 0,133 & $\mathbf{0 , 1 3 2}$ \\
\hline Sup Ayam & 0,300 & 0,433 & 0,324 & 0,400 & $\mathbf{0 , 3 6 4}$ \\
\hline Jumlah & $\mathbf{1 , 0 0 0}$ & $\mathbf{1 , 0 0 0}$ & $\mathbf{1 , 0 0 0}$ & $\mathbf{1 , 0 0 0}$ & $\mathbf{1 , 0 0 0}$ \\
\hline
\end{tabular}

TABEL 21

MATRIKS PENJUMLAHAN TIAP BARIS

\begin{tabular}{|c|c|c|c|c|c|}
\hline Alternatif & $\begin{array}{c}\text { Udang } \\
\text { Goreng } \\
\text { Tepung }\end{array}$ & $\begin{array}{c}\text { Tumis } \\
\text { Tahu Saus } \\
\text { Tiram }\end{array}$ & $\begin{array}{c}\text { Tumis } \\
\text { Brokoli }\end{array}$ & $\begin{array}{c}\text { Sup } \\
\text { Ayam }\end{array}$ & Jumlah \\
\hline $\begin{array}{c}\text { Udang } \\
\text { Goreng } \\
\text { Tepung }\end{array}$ & 0,048 & 0,051 & 0,033 & 0,061 & $\mathbf{0 , 1 9 2}$ \\
\hline $\begin{array}{c}\text { Tumis Tahu } \\
\text { Saus Tiram }\end{array}$ & 0,431 & 0,456 & 0,660 & 0,364 & $\mathbf{1 , 9 1 2}$ \\
\hline $\begin{array}{c}\text { Tumis } \\
\text { Brokoli }\end{array}$ & 0,192 & 0,091 & 0,132 & 0,121 & $\mathbf{0 , 5 3 6}$ \\
\hline Sup Ayam & 0,288 & 0,456 & 0,396 & 0,364 & $\mathbf{1 , 5 0 4}$ \\
\hline
\end{tabular}

TABEL 22

MATRIKS RASIO KONSISTENSI

\begin{tabular}{|c|c|c|c|}
\hline Alternatif & \begin{tabular}{|c|} 
Jumlah \\
Tiap Baris \\
\end{tabular} & Prioritas & Hasil \\
\hline Udang Goreng Tepung & 0,192 & 0,048 & 4,011 \\
\hline Tumis Tahu Saus Tiram & 1,912 & 0,456 & 4,194 \\
\hline Tumis Brokoli & 0,536 & 0,132 & 4,063 \\
\hline Sup Ayam & 1,504 & 0,364 & 4,128 \\
\hline \multicolumn{3}{|c|}{ Jumlah } & 16,396 \\
\hline
\end{tabular}

Jumlah (jumlah dari nilai-nilai hasil) $=16,396$

$\mathrm{n}$ (jumlah kriteria) $=4$

$\lambda$ maks $(16,396 / 4)=4,0990$

$\mathrm{CI}=(4,0990-4) /(4-1)=0,0330$

$\mathrm{CR}=0,0330 / 0,90=0,0367$

C. Menghitung Hasil

TABEL 23

NILAI PRIORITAS MASING-MASING MENU MAKANAN BAGI ANAK TIAP KRITERIA

\begin{tabular}{|c|c|c|c|c|}
\hline Alternatif $\backslash$ Kriteria & 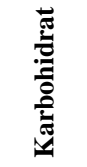 & 预 & 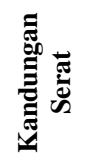 & 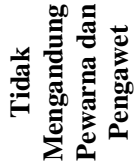 \\
\hline $\begin{array}{c}\text { Udang Goreng } \\
\text { Tepung }\end{array}$ & 0,174 & 0,511 & 0,212 & 0,048 \\
\hline $\begin{array}{c}\text { Tumis Tahu Saus } \\
\text { Tiram }\end{array}$ & 0,293 & 0,035 & 0,048 & 0,456 \\
\hline Tumis Brokoli & 0,044 & 0,173 & 0,422 & 0,132 \\
\hline Sup Ayam & 0,489 & 0,280 & 0,319 & 0,364 \\
\hline Prioritas Kriteria & $\mathbf{0 , 0 8 7}$ & 0,307 & 0,066 & 0,540 \\
\hline
\end{tabular}

TABEL 24

NILAI PRIORITAS GLOBAL MASING-MASING MENU MAKANAN BAGI ANAK

\begin{tabular}{|c|c|c|c|c|c|}
\hline $\begin{array}{l}\text { Alternatif } \backslash \\
\text { Kriteria }\end{array}$ & 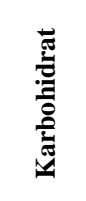 & 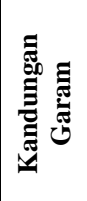 & 㤩 & 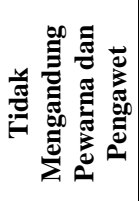 & 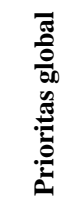 \\
\hline $\begin{array}{c}\text { Udang Goreng } \\
\text { Tepung }\end{array}$ & 0,174 & 0,511 & 0,212 & 0,048 & 0,212 \\
\hline $\begin{array}{l}\text { Tumis Tahu } \\
\text { Saus Tiram }\end{array}$ & 0,293 & 0,035 & 0,048 & 0,456 & 0,286 \\
\hline Tumis Brokoli & 0,044 & 0,173 & 0,422 & 0,132 & 0,156 \\
\hline Sup Ayam & 0,489 & 0,28 & 0,319 & 0,364 & 0,346 \\
\hline
\end{tabular}


Berdasarkan nilai prioritas global dari tabel 23 diperoleh nilai tertinggi sebagai jenis makanan adalah alternatif Sup Ayam dengan nilai 0,346 menempati urutan 1 .

\section{Perancangan Sistem}

1. Use Case Diagram

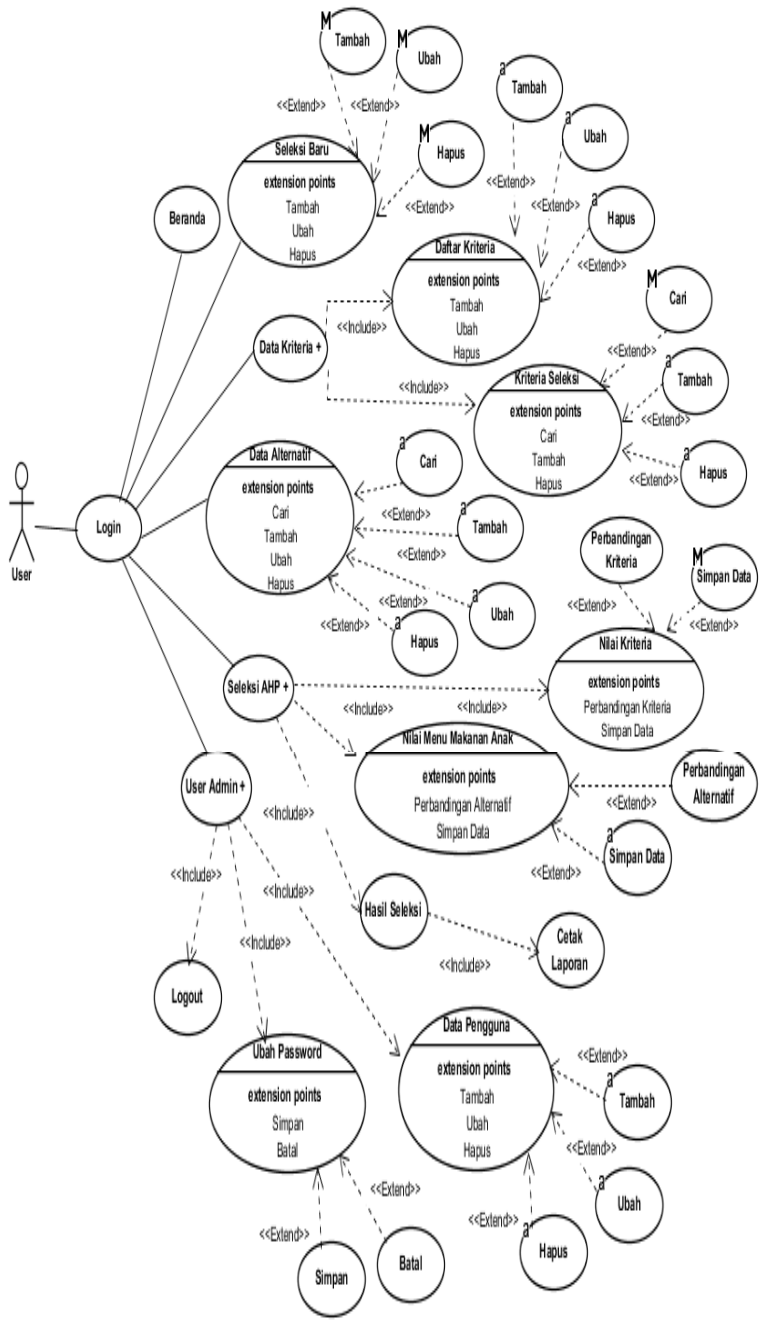

Gambar 2. Use Case Diagram SPK Pemilihan Menu Makanan

\section{Class Diagram}

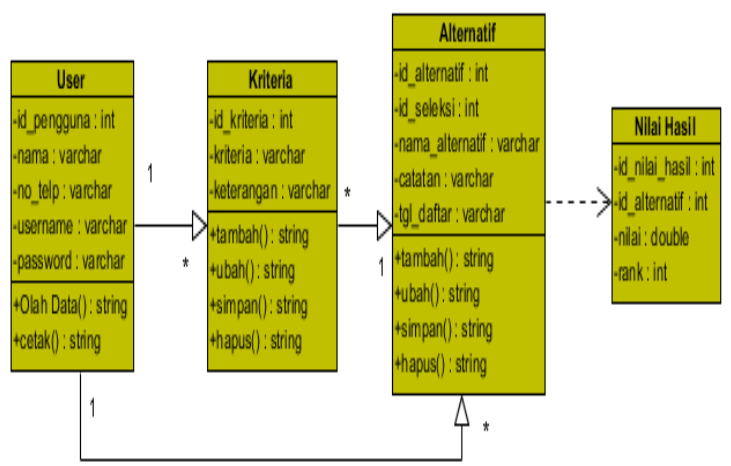

Gambar 3. Class Diagram SPK Pemilihan Menu Makanan
3. Sequence Diagram

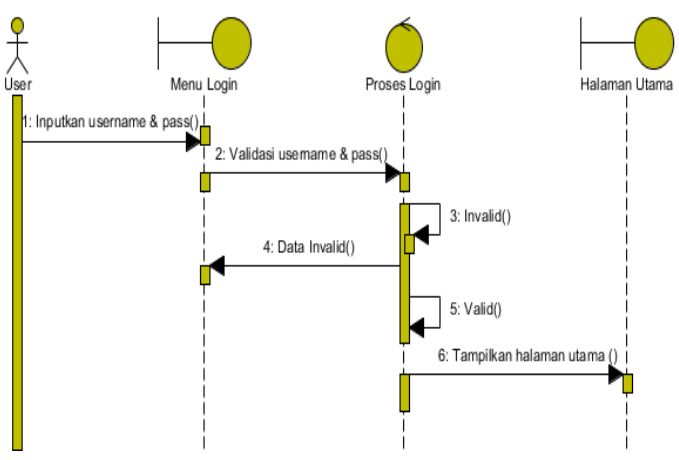

Gambar 4. Sequence Diagram Login User

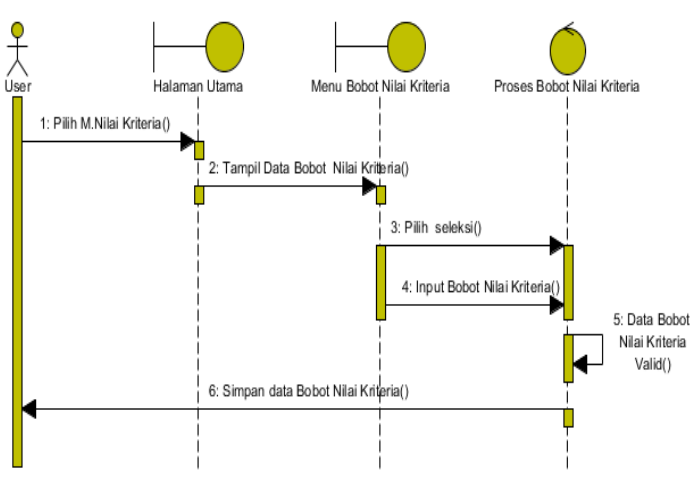

Gambar 5. Sequence Diagram Olah Data Nilai Kriteria

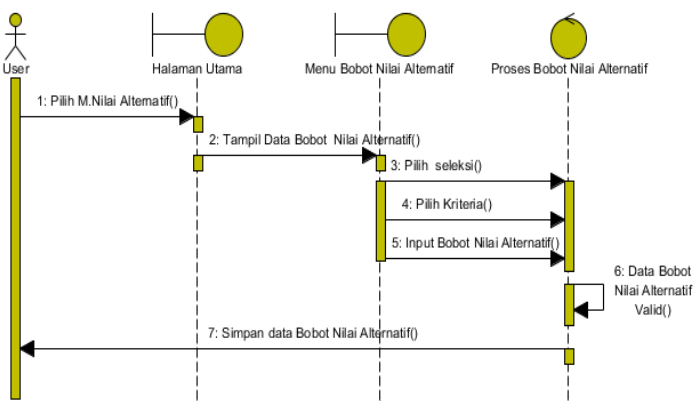

Gambar 6. Sequence Diagram Olah Data Nilai Alternatif

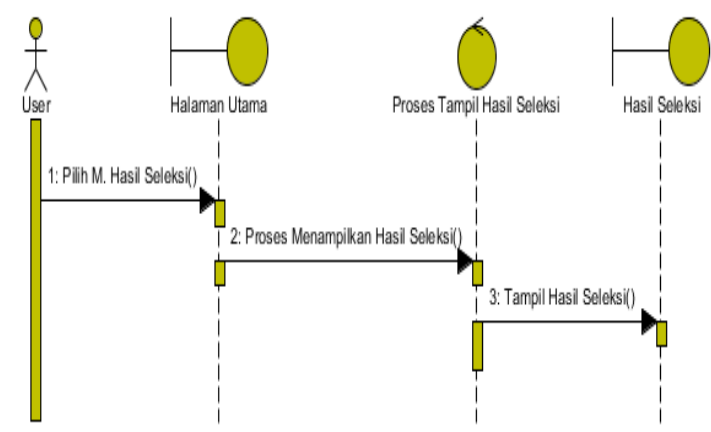

Gambar 7. Sequence Diagram Melihat Hasil 


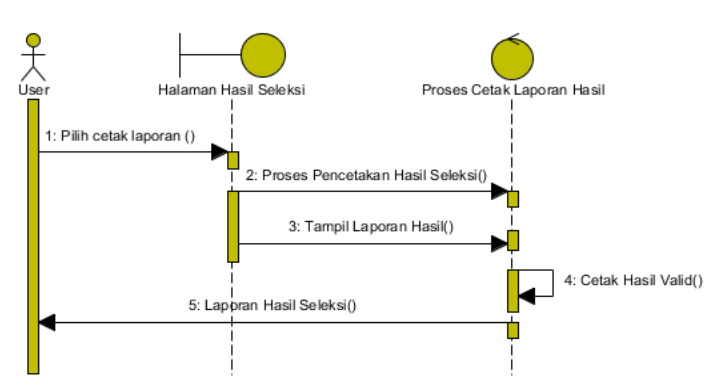

Gambar 8. Sequence Diagram Mencetak Hasil

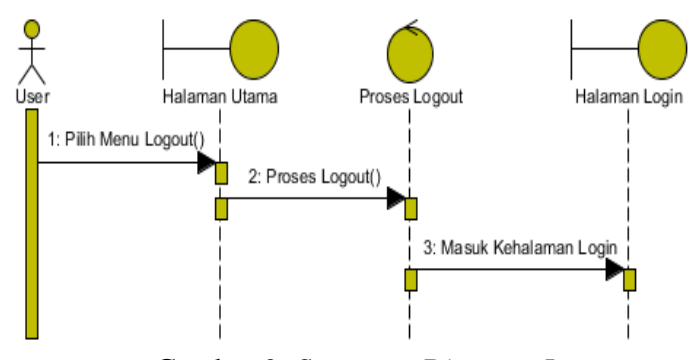

Gambar 9. Sequence Diagram Logout

4. Activity Diagram

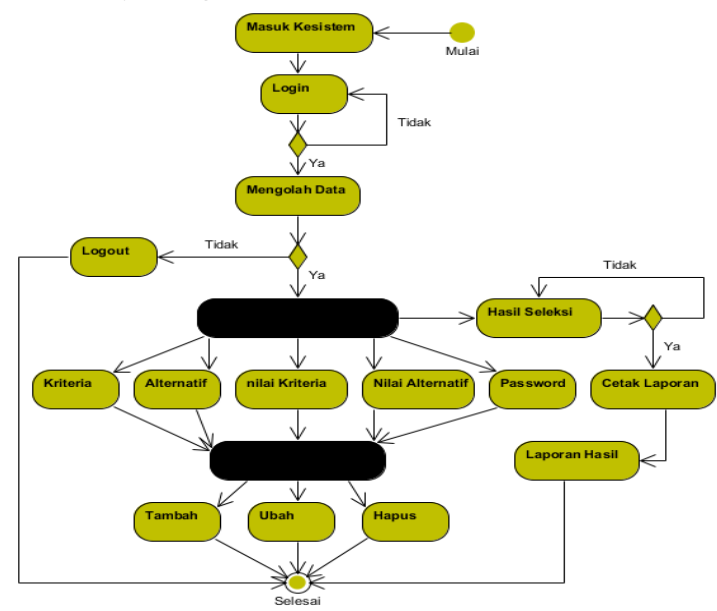

Gambar 10. Activity Diagram SPK Pemilihan Menu Makanan

\section{E. Implementasi Sistem}

1. Form Menu Utama

Berisikan menu-menu dan sub menu yang terdapat pada sistem admin yang telah dirancang sebelumnya.

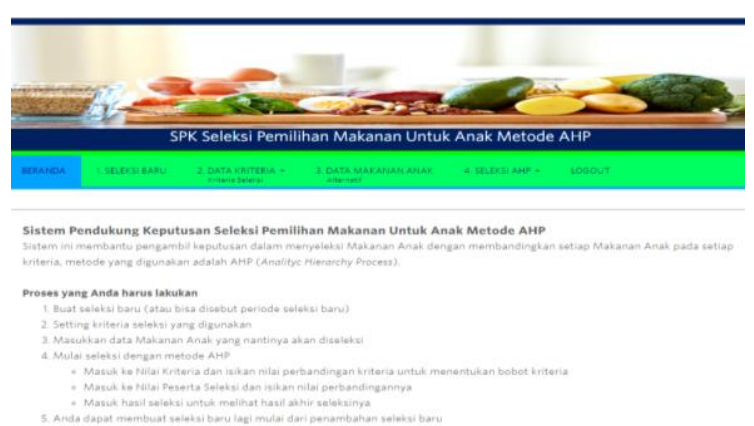

Gambar 11. Form Menu Utama

2. Form Data Kriteria

Form data kriteria merupakan penginputan, pengeditan, pembatalan dan penghapusan data kriteria.

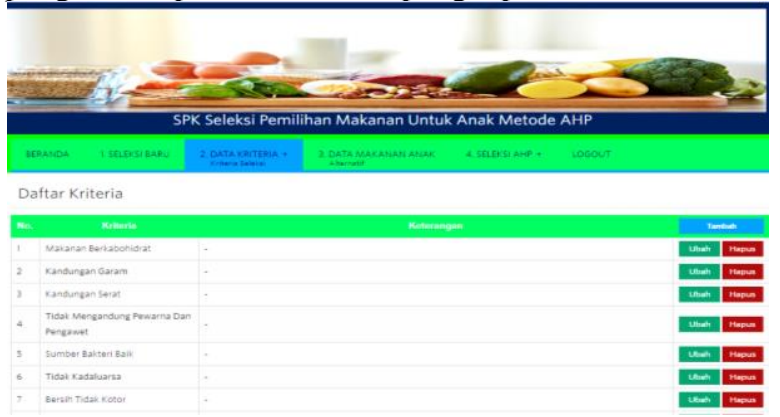

Gambar 12. Form Data Kriteria

3. Form Data Alternatif

Form data alternatif berisikan perintah pencarian, edit, tambah dan penghapusan data alternatif menu makanan.

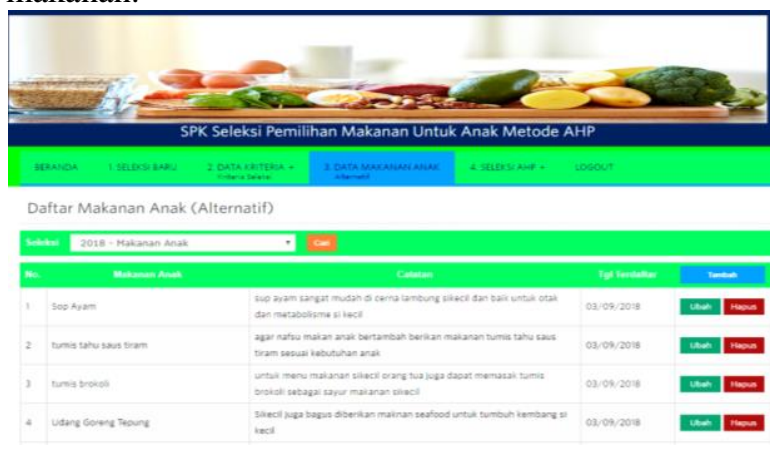

Gambar 13. Form Data Alternatif

4. Form Hasil Seleksi

Berisikan laporan hasil dari seleksi metode AHP untuk selanjutnya dicetak.

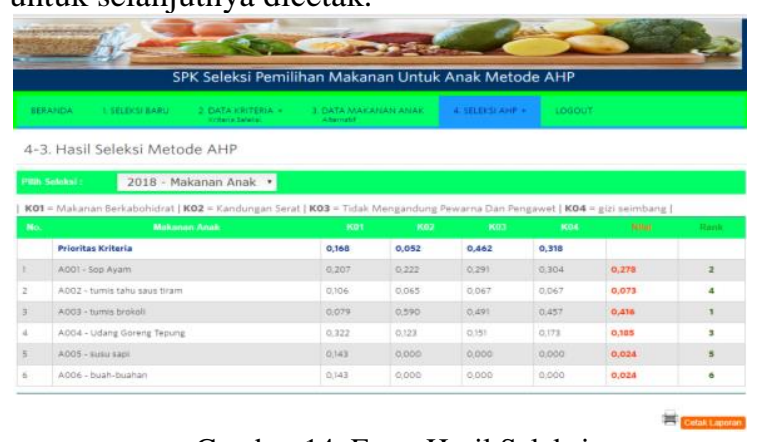

Gambar 14. Form Hasil Seleksi 


\section{A. Kesimpulan}

Dari uraian bab sebelumnya, ada beberapa hal yang bisa dicermati pada sistem pendukung keputusan pemilihan menu makanan bagi anak dengan menggunakan metode AHP yaitu sebagai berikut:

1. Sistem pendukung keputusan penentuan menu makanan dapat membantu TK Taqwa Perkebunan Gunung Melayu dengan menggunakan metode AHP.

2. Membantu menyeleksi menu makanan di TK Taqwa Perkebunan Gunung Melayu yang dipilih berdasarkan kriteria dan penilaian alternatif.

3. Membantu orang tua maupun TK Taqwa Perkebunan Gunung Melayu untuk menentukan menu makanan bagi anak.

4. Sistem ini dibuat dinamis sehingga jika ada perubahan atau penambahan terhadap penentuan jenis dapat dilakukan dengan mudah.

\section{B. Saran}

Agar sistem dapat digunakan dan berjalan dengan baik serta sesuai dengan apa yang diharapkan, maka disarankan hal-hal sebagai berikut:

1. Sistem pendukung keputusan ini perlu beberapa penyempurnaan dari segi tampilan, karena belum dilengkapinya sistem pendukung keputusan dalam pemilihan menu makanan bagi anak.

2. Sistem pendukung keputusan ini dapat dikembangkan dengan menggunakan metode yang lain yang bisa memberikan nilai kepastian terhadap kriteria dan nilai alternatif.

3. Sistem pendukung keputusan ini diharapkan untuk ke depannya dapat dikembangkan lagi dari sistem berbasis offline menjadi berbasis online.

\section{DAFTAR PUSTAKA}

[1] Sri Yuni Lestari, Kusrini. 2012. "Membangun Aplikasi Mobile "Resep Masakan Asia (Indonesia, China, Jepang)" Berbasis Android". Jurnal DASI. Vol. 13, No. 1, Hal. 36-41, ISSN : 1411-3201.

[2] Lia Kurniawaty. 2017. "Peningkatan Pengetahuan Tentang Makanan Sehat Melalui Kegiatan Bermain Cooking Class". Jurnal CARE (Children Advisory Research and Education). Vol. 4, No. 2, Hal. 1-17.

[3] Eka Iswandy. 2015. "Sistem Penunjang Keputusan untuk Menentukan Penerimaan Dana Santunan Sosial Anak Nagari Dan Penyalurannya Bagi Mahasiswa dan Pelajar Kurang Mampu di Kenagarian Barung-Barung Balantai Timur". Jurnal TEKNOIF. Vol. 3, No. 2, Hal. 70-174, ISSN : 23382724.

[4] Frangky, Joni Devitra. 2016. “Analisis dan Perancangan Sistem Informasi Pengggajian pada PT. Sumber Agrindo Sejahtera". Jurnal Manajemen Sistem Informasi. Vol 1, No. 2, Hal. 185-190, ISSN : 2540-8011.
[5] Yustria Handika Siregar. 2017. "Sistem Pendukung Keputusan Data Alumni Sarjana Komputer Menggunakan Metode Inferensi Mamdani Berbasis Matlab". Jurnal Teknologi Informasi(JurTI). Vol. 1, No. 1, Hal. 33-41, P-ISSN 2580-7927.

[6] Eko Darmanto, Noor Latifah, Nanik Susanti. 2014. "Penerapan Metode AHP (Analythic Hierarchy Process) untuk Menentukan Kualitas Gula Tumbu". Jurnal SIMETRIS. Vol. 5, No. 1, Hal. 75-82. ISSN: 2252-4983. 